\title{
Microbial Effect of Refuse Dump on the Composition of Leafy Vegetables Grown in the Vicinity of Dump Site Along River Benue, Mubi Road, Yola
}

\author{
Enock Dashu
}

Adamawa state college of Agriculture, P.M.B 2088, Ganye-Nigeria

\begin{abstract}
Microbial quality of vegetables grown in the vicinity of dumpsite along river Benue basin Yola Adamawa state was investigated to determine the effect of the wastes. A total of twenty samples were studied, from each of vegetable, soil and water at different distances 50, 100 and $200 m$ from the dumpsite. Microbial analysis showed that total bacterial, mold and yeast, and coliform bacteria counts exceeded the 1,000 CFU/100ml guideline for water used in fresh produce. The result shows that total bacterial count was found to be significantly higher in the soil ranging from $4.3 \times 10^{5}-4.78 \times 10^{6}$ followed by irrigation water ranging from $1.0 \times 10^{4}-3.66 \times 10^{6}$ and the least was the vegetable ranging from $1.0 \times 10^{4}-9.0 \times 10^{4}$. Coliform bacteria count was found to be higher in the irrigation water ranging from $2.0 \times 10^{4}-1.2 \times 10^{5}$ followed by the vegetables ranging from $1.0 \times 10^{4}-2.0 \times 10^{4}$ and no growth of coliform was found in the soil. Mold and yeast was found to be significantly higher in the soil ranging froml.0 $\times 10^{4}$ TNC and was absent in the vegetables and water respectively. The higher level of microorganism observed in the dump site vegetables compared with the control vegetables show that refuse dump contribute to the microbial load in the study site. This implies that the microbial quality of vegetables may pose a health risk to the people who consume them if not properly prepared.
\end{abstract}

Keywords-Microbial, Refuse dump, Vegetables, Yola.

\section{INTRODUCTION}

The nutritional significance of vegetables in healthy diet cannot be over emphasized. Vegetables are known to be good source of vitamins, minerals and dietary fiber. They also add flavor (color and taste) as well as aesthetic appeal to diet. Eating vegetables provides health benefits, people who eat more vegetables as part of an overall healthy diet are likely to have a reduced risk of some heart diseases like stroke, cancers, obesity, type 2 diabetes etc. That is why www.ijeab.com the consumption of fresh fruits and vegetables is encouraged by government health agencies (James J.B and T. Ngarmsak, 2011)

However, leafy green vegetables were identified as the commodity group of highest concern from a microbiological safety perspective. This commodity grouping was considered to include all vegetables of a leafy nature and of which the leaf is the intended for consumption such as lettuce (all varieties), spinach, cabbages, chicory, leafy fresh herbs (e.g. cilantro, basil, parsley) and watercress. (WHO/FAO, 2008)

The land around river Benue basin stretching to Lake Gerio, has long been used for both wet and dry season farming. This area also served as a dumpsite for refuse or domestic waste. Waste water from the neibouring wards passes down the area through connecting drainages. During the rainy season, when there is so much water, contamination of vegetables may take place at all stages during pre and postharvest stages (De Roever, 1999). Row fruits and vegetables are known potential for a wide range of microorganisms, including human pathogen (Tambekar and Mundhada, 2006). Food-borne bacterial pathogens commonly detected in fresh vegetables are coliform bacteria, E. coli, staphylococcus aureus and Salmonella sp. (Tambekar and Mundhada, 2006).

Microbiological risk assessment is an emerging tool for the evaluation of the safety of food and water supplies. Different organizations have suggested that microbiological risk assessment should be carried out so that appropriate remedial measures can be adopted to curtail the incidences of food-borne illness as a result of consumption of contaminated foods. Microbes, mainly the coliforms group have been used extensively as indicator of microbiological quality of water and food. Their presence indicates improper treatment or post-disinfection contamination (Ciira, 2003). 
The main objectives of these study was to investigate the potential hazard of microorganism associated with vegetables grown in the vicinity of refuse dump along river Benue basin Yola, Adamawa state and highlight the importance of proper preparation before consumption and also investigate the source of contamination and prevalence of pathogenic microorganisms their consumption is encouraged in many countries by government health agencies toprotect against a range of illnesses such as cancers and cardiovascular diseases. However, fruits and vegetables, and in particular leafy greens that are consumed raw, are increasingly being recognized as important vehicles for transmission of human pathogens that were traditio- nally associated with foods of animal origin. Their consumption is encour-aged in many countries by government health agencies to protect against a range of illnesses such as cancers and cardiovascular diseases. However, fruits and vegetables, and in particular leafy greens that are consumed raw, are increasingly being recognized as important vehicles for transmission of human pathogens that were traditio- nally associated with foods of animal origin.

\section{Source of materials}

Representative samples of vegetables, water and soil were obtained from the study site along the River Benue Basin, Shinko site. Instruments, tools and general laboratory glass wares were obtained from Food science and Technology laboratory Modibbo Adama University of Technology Yola.

\section{STUDY AREA}

Yola is the capital city and the administrative center of Adamawa State Nigeria. Located on the Benue river, it has a population of 336,648 (2010). With coordinates $9^{\circ} 13^{\prime} 48^{\prime \prime} \mathrm{N} 12^{\circ} 27^{\prime} 36^{\prime \prime} \mathrm{E} / 9,23000^{\circ} \mathrm{N} 12,46000^{\circ} \mathrm{E}$ and its elevation is $1,965 \mathrm{ft}$. above sea level $(599 \mathrm{~m})$ The specific site is in river Benue bank in Yola bye pass where variety of vegetables are cultivated and it is chosen because the area is currently undergoing severe degradation resulting from municipal waste disposal.

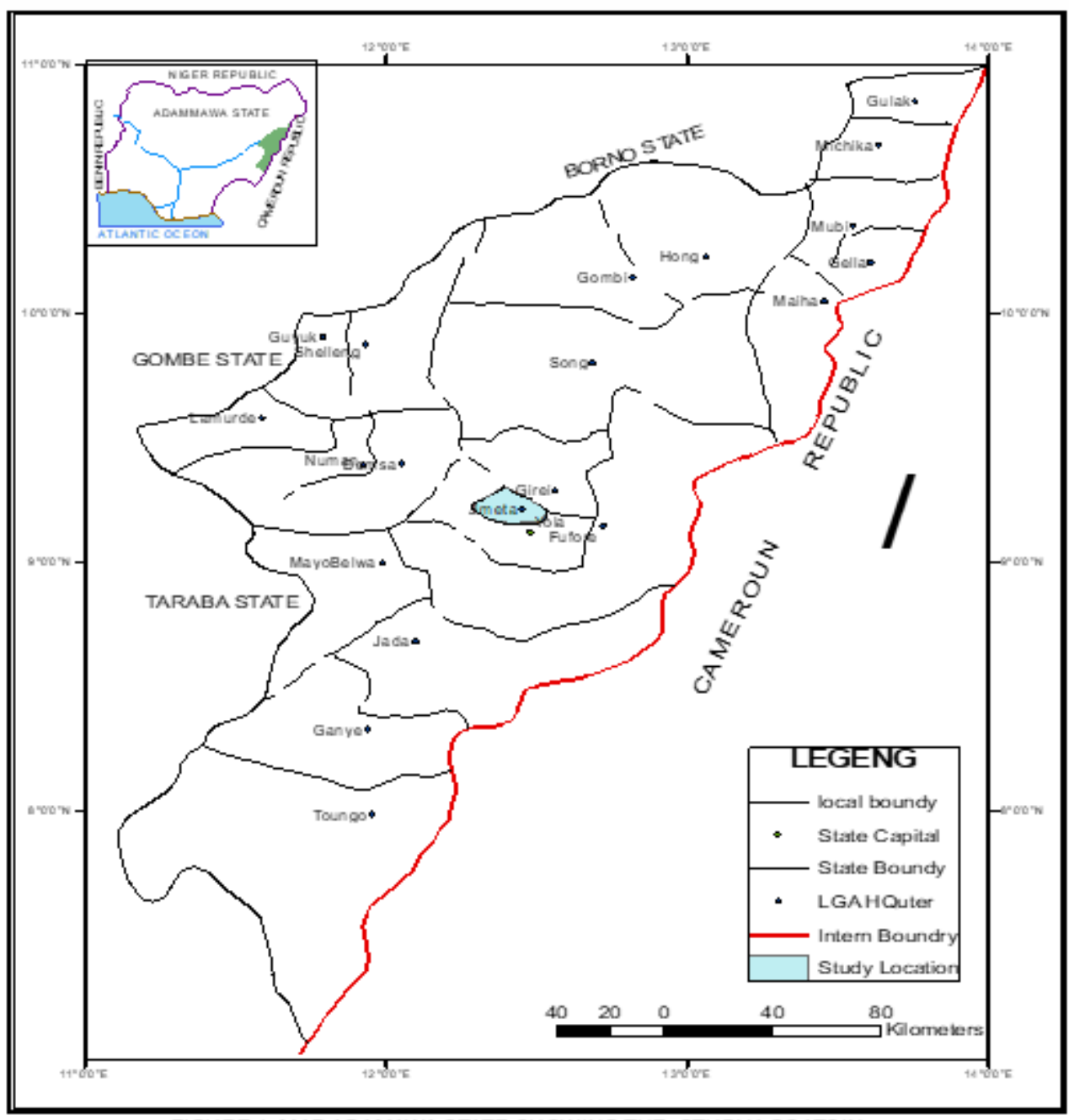

Fig.1: Map Adamawa state showing the study Location 


\section{Study Design}

The research was carried out in two phases; the first phase was preliminary investigations involving the history of the dumping site, the variety of materials dumped at that site and the estimate of the size or volume of the dump.

The second phase was the analytical process which involves the environmental media, sample collection, preparation and laboratory work.

\section{Preliminary investigation of the refuse dump}

The information was collected through interviews, field survey measurements, and direct observation of the type and nature of waste, as well assess the volume of the dump site and then evaluate the role of government and community in managing the site.

\section{ANALYTICAL METHODS}

The analytical phase involved microbiological analysis viz: total bacterial plate count (TBPC) was determined by the procedure described by V.A Jideani and I.A Jideani (2006). Yeast and Mould count was determined by the procedure described by Harrigan and McCance(1976). Coliforms bacteria was determined by the procedure described by Harrigan and McCance(1976).

Experimental Design

Figure 3 is a $5 \times 4$ factorial design for the study of microbial contamination of vegetables, water and soil.

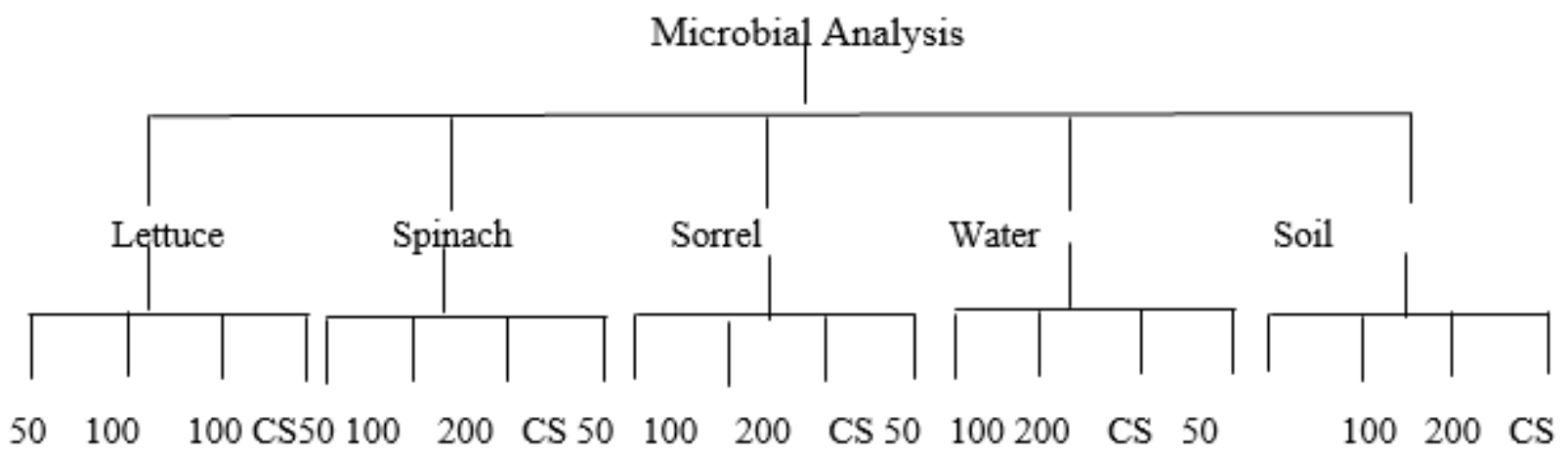

$\mathrm{CS}=$ Control sample, $\mathrm{m}=$ meters

\section{Sampling Procedure}

Three (3) popular vegetables namely Lettuce, Sorrel and spinach with their associated soil, water was taken at a distance of 50 meters, 100 meters, 200 meters from the edge of the selected area. Reference vegetable sample was taken from a farm in Loko Song L.G.A where refuge is not close by. All the Soil samples were collected from the upper soil layer of $0-5 \mathrm{~cm}$ to the laboratory for analysis.

\section{RESULTS}

Table.1: Results of the microbial analysis of vegetables (lettuce, spinach and sorrel) water and soil samples (cfu/ml)

\begin{tabular}{lllll}
\hline $\begin{array}{l}\text { Enviro. } \\
\text { Media }\end{array}$ & Distances & coliform count & total bacterial count & mold \& yeast count \\
\hline Lettuce & $50 \mathrm{~m}$ & $0.0 \times 10^{4}$ & $9.0 \times 10^{4}$ & $0.0 \times 10^{4}$ \\
& $100 \mathrm{~m}$ & $1.0 \times 10^{4}$ & $2.0 \times 10^{4}$ & $0.0 \times 10^{4}$ \\
& $200 \mathrm{~m}$ & $2.0 \times 10^{4}$ & $7.0 \times 10^{4}$ & $0.0 \times 10^{4}$ \\
& Control & $0.0 \times 10^{4}$ & $5.0 \times 10^{4}$ & $0.0 \times 10^{4}$ \\
Spinach & $50 \mathrm{~m}$ & $1.0 \times 10^{4}$ & $3.0 \times 10^{4}$ & $0.0 \times 10^{4}$ \\
& $100 \mathrm{~m}$ & $0.0 \times 10^{4}$ & $8.0 \times 10^{4}$ & $0.0 \times 10^{4}$ \\
& $200 \mathrm{~m}$ & $1.0 \times 10^{4}$ & $4.0 \times 10^{4}$ & $0.0 \times 10^{4}$ \\
& Control & $0.0 \times 10^{4}$ & $2.0 \times 10^{4}$ & $0.0 \times 10^{4}$ \\
& $50 \mathrm{~m}$ & $0.0 \times 10^{4}$ & $2.0 \times 10^{4}$ & $0.0 \times 10^{4}$ \\
& $100 \mathrm{~m}$ & $0.0 \times 10^{4}$ & $3.0 \times 10^{4}$ & $0.0 \times 10^{4}$ \\
& $200 \mathrm{~m}$ & $2.0 \times 10^{4}$ & $1.0 \times 10^{4}$ & $0.0 \times 10^{4}$
\end{tabular}




\begin{tabular}{lllll}
\multirow{3}{*}{ Water } & Control & $0.0 \times 10^{4}$ & $1.0 \times 10^{4}$ & $0.0 \times 10^{4}$ \\
& $50 \mathrm{~m}$ & $1.2 \times 10^{5}$ & $3.66 \times 10^{6}$ & $0.0 \times 10^{4}$ \\
& $100 \mathrm{~m}$ & $2.0 \times 10^{4}$ & $2.52 \times 10^{6}$ & $0.0 \times 10^{4}$ \\
& $200 \mathrm{~m}$ & $3.0 \times 10^{4}$ & $6.0 \times 10^{4}$ & $0.0 \times 10^{4}$ \\
Soil & Control & $0.0 \times 10^{4}$ & $1.0 \times 10^{4}$ & $0.0 \times 10^{4}$ \\
& $50 \mathrm{~m}$ & $0.0 \times 10^{4}$ & $7.3 \times 10^{5}$ & $\mathrm{TNC}$ \\
& $100 \mathrm{~m}$ & $0.0 \times 10^{4}$ & $7.7 \times 10^{5}$ & $4.0 \times 10^{4}$ \\
& $200 \mathrm{~m}$ & $0.0 \times 10^{4}$ & $4.78 \times 10^{6}$ & $3.0 \times 10^{4}$ \\
& Control & $0.0 \times 10^{4}$ & $4.3 \times 10^{5}$ & $1.0 \times 10^{4}$
\end{tabular}

Analysis was performed in triplicates

TNC: too numerous to count

\section{DISCUSSION OF RESULT}

\section{Vegetables}

The average total bacterial count, coliform count and the mold and yeast count from four distances were represented in table4.

Total bacterial count of the vegetables range from $1.0 \times 10^{4}$ $-9.0 \times 10^{4} \mathrm{cfu} / \mathrm{ml}$ and the coliform count range from $1.0 \times$ $10^{4}-2.0 \times 10^{4} \mathrm{cfu} / \mathrm{ml}$. it is observed that the overall microbial load of the vegetables was found to be independent of the distance from the dumpsite. This implies that the microbial source is not due to the dumpsite soil but, it is coming from the irrigation water because, irrigation water was observed to have the highest microbial growth and which serves as a potential source of contamination of vegetables. The result is in agreement with that reported by Chaturvedi et al. (2013) And Halablab et al., (2011). They reported presence of microbial contamination in vegetables There were significant difference in the total bacterial count growth found in each distance but, in the coliform count there were no difference. There were also significant difference between the samples in the study site and the control. This indicates that there is indeed effect of the dumpsite (effluent water) on the quality of the vegetables. These findings correspond with the report recorded by Abakpa et al., (2013) on the microbial quality of irrigation water and irrigated vegetables in Kano state Nigeria. Majority of farmers use water from drains with low water quality.

\section{Irrigation water}

Total bacterial count and coliforms count are higher in the irrigation water compare with the vegetables and soil samples. The microbial load was found to decrease with distances increasing from the dumpsite. Total bacterial count range from $1.0 \times 10^{4}-3.66 \times 10^{6} \mathrm{cfu} / \mathrm{ml}$ and the coliform count range from $2.0 \times 10^{4}-1.2 \times 10^{5} \mathrm{cfu} / \mathrm{ml}$. Mold and yeast were not found in the irrigation water.
The higher growth showed by water samples is an indication that the irrigation water serves as the potential source of contamination these result therefore, reflect the exposure of the vegetables to contamination during irrigation and in particular, the existence of favorable conditions for the multiplication of microorganisms. Previous studies by Abakpa et al., (2013). Reveals that irrigation water source received pollutant from various effluents discharged from industries, domestic sewages, abattoir and other non-point source of pollution.

\section{Soil}

Total bacterial count range from $4.3 \times 10^{5}-4.78 \times 10^{6}$ with the highest count coming from $200 \mathrm{~m}$ distance and lowest count from the control sample. Soil inhabit microorganism under favorable condition therefore, the soil serves as a potential source of contamination Many vegetables grow low to the ground where they are likely to come in contact with the soil. If the soil has been treated with improperly treated animal manure as fertilizer or irrigated with contaminated water vegetables are also likely to be contaminated.

Coliform bacteria count showed no growth this indicates that most of the coliforms obtained in vegetables are coming from the source of irrigation water. The result showed that bacterial count was higher in the soil than water. Previous studies indicated that Mold and yeast count range from $1.0 \times 10^{4}-\mathrm{TNC}$ with the highest coming from $50 \mathrm{~m}$ distance and lowest from the control sample. Mold and yeast growth was only found in the soil samples. The high mold and yeast count in the soil sample might be due to dumpsite waste rich organic matter as stated by Oyedele $e t$ al., (2009)

\section{Summary}

A total of twenty samples were collected for the study, three samples from each of vegetable, soil and water were taken 
from three different distances and each with their control sample.

The result shows that total bacterial count was found to be significantly higher in the soil ranging from $4.3 \times 10^{5}-4.78$ $\mathrm{x} 10^{6}$ followed by irrigation water ranging from $1.0 \times 10^{4}$ $3.66 \times 10^{6}$ and the least was the vegetable ranging from 1.0 $\times 10^{4}-9.0 \times 10^{4}$. Coliform bacteria count was found to be higher in the irrigation water ranging from $2.0 \times 10^{4}-1.2 \mathrm{x}$ $10^{5}$ followed by the vegetables ranging from $1.0 \times 10^{4}-2.0$ x $10^{4}$ and no growth of coliform was found in the soil. Mold and yeast was found to be significantly higher in the soil ranging from1.0 $\times 10^{4}-\mathrm{TNC}$ and was absent in the vegetables and water respectively.

\section{Conclusion}

Regular monitoring of contamination is very important in food industry to prevent food poisoning and other health hazards. In the present work, the microbial loads of soil, water and three different vegetables grown around dumpsite were examined. The result was found to be higher than the acceptable limits. This implies that the microbial quality of vegetables may pose a health risk to the people who consume them if not properly prepared.

\section{Recommendation}

The high bacterial load in the vegetable samples could serve as an indicator for the need to promote awareness about the possible health hazards that could be due to proximity of these vegetables to the dumpsite. There is therefore, the need for regulatory bodies to ensure that microbiological standards are established and practiced by farmers of vegetables.

Since the dumpsite was found to directly contribute to the pollution of the soils, vegetables and irrigation water, and the fact that it is an illegal entity, as such dumping should be stopped and the site properly closed.

Again, public enlightenment on proper handling of wastes in the society should be intensified in order to reduce wastes related problems along the food chain.

Lastly people should thoroughly wash the vegetables with tap water or salt water in other to reduce the microbial load especially lettuce that is consume fresh.

\section{REFERENCES}

[1] Beuchat, L.R. and Cousin, M.A. (2001). Microbiological Examination of Foods.

[2] Chaturvedi, M, Kumar, V.,Sigh, D. and Kumar, S.(2013). Assessment of microbial load of some common vegetables among two different socioeconomic groups.
[3] Ciira Kiiyukia (2003). Laboratory Manual of food Microbiology for Ethiopian Health and Nutrition Research Institute (Food Microbiology Laboratory) UNIDO Project (INIDO / Food Analysis Microbiology).

[4] Cotran, R.S., Kumar, V. \& Robbins, S.L. (1989). Robbins pathologic basis of disease. Philadelphia, PA: W.B, Saunders Company.

[5] De Roever. C,(1999). Microbiological safety evaluations and recommendation on fresh produce. Food Control.

[6] Francis, G.A., Thomas C. and O'Beirine D. (1999). The microbiological safety of minimally processed vegetables. International Journal of Food Science and Technology.

[7] Francis, G.A., Thomas C. and O'Beirine D. (1999). The microbiological safety of minimally processed vegetables. International Journal of Food Science and Technology.

[8] Gyoh SK.(2011) Cholera epidemics in Nigeria an indictment of the shameful neglect of government. Africa Health.

[9] IS 5401(P-II): 2002. General Guidance for the Enumeration of Coliforms. Part 2 Most probable number technique.

[10] IS 5402:2002. General Guidance for the enumeration of Micro-organisms-colony count technique at $30^{\circ} \mathrm{c}$.

[11] Kitty Cathy Mngoli and Tinna Austen Ng'ong'olaManani(2014). Microbiological quality of fresh lettuce sold at Lilongwe market, Malawi:Does purchasing time matter? African Journal of microbiology Research.

[12] Magaji. J. Y. (2012). Effect of waste dump on the quality of plant cultivated around Mpape dumpsite FCT Abuja. Nigeria. Ethiopian Journal of Environmental Studies and management EJESM Vol.5 no.4 (suppl.2).

[13] Oyeleke, S.B and Istifanus N.(2009) The microbiological effect of Hospital waste on the environment. African Journal of biotechnology.

[14]P. Amoah, P. Drechsel, R.C Abaidoo w.j Ntow (2005). Pesticide and pathogen contamination of vegetables in Ghana's urbran markets.

[15] Tambekar, D.H. and Mundhada, R.H.( 2006). Bacteriological quality of salad vegetables sold in Amravati city (India). Journal of Biological Science.

[16] UNESCO (2010). Nigeria project for revitalization of TVE in Nigeria instructional/teaching materials. 